\title{
Classifying Word Association Test (WAT) Response in Song Study at Students Senior High School 1 Sungai Aur
}

\author{
Trisa Wendari ${ }^{* *}$ and M. Zaim ${ }^{2}$ \\ ${ }^{1}$ English Department, FBS Universitas Negeri Padang, Padang, Sumatra Barat 25131, Indonesia \\ ${ }^{2}$ English Department, FBS Universitas Negeri Padang, Padang, Sumatra Barat 25131, Indonesia \\ *Corresponding author. Email: trisa.windari445@gmail.com
}

\begin{abstract}
Vocabulary development is a significant purpose in any language teaching. The term that manages vocabularies in the person is named 'mental lexicon'. The mental lexicon describes a dictionary that upgrades every word, meaning, and associate them with another word in the mind. Word Association Test is one measurement to know how depth vocabularies understanding are. It also called Word Affiliation Test and a greatly-renowned research technique in linguistic and psychology research by using word stimulus to acquire the lexical relation amid words. In senior High school, song study is taught at the end of the syllabus. The researcher connected the song with the vocabularies of students and tried to examine the word types of association they are used so they feel easy and enjoyed learning English and have a significant result in their study. The classification of word association composition concentrated on the two central fundamentals of language: syntagmatic; It should be connected with a phrase or syntactic framework and paradigmatic; involve another words or syllable that might switch connection. This research aims to explore the students' dept understanding of the word in the mind and to apply it in the English study. This is a qualitative study and analyzes the response of the students based on syntagmatic and paradigmatic types. The source of this research is got from a preliminary student's senior high school at Sungai Aur. Then, the data are analyzed and classified into syntagmatic and paradigmatic.
\end{abstract}

Keywords: Mental lexicon, Word Association test, Vocabulary

\section{INTRODUCTION}

In communication, language turns into a medium to convey the importance of the theme which is talked about. Vocabulary is the fundamental base of communication because many vocabularies keep in the mind and the more understanding each counter-pack talking about. Carefully speaking, our insight into words incorporates morphological, syntactic, and phonological considerably another poor stage appearance like radicals, shapes, and strokes. The mechanism accountable to manage this accumulation of words is conventionally note in the documents called the mental lexicon or commonly as the "human word-store" [1]. The mental lexicon includes an explanation of comprehensive content of words, each notable to differ level by language user. The mental lexicon is a challenging composition whereabouts words are regulated in term of their syntax, semantics, and phonology as nice as other non-linguistic features. [2]

Aspects of linguistics from mental lexicon are represented in the arrangement of language, and, contrarily, that the humanistic explanation collected in speech assists to the evolution of recent mental lexicons in children being and the accompaniment of disposition to the existent lexicons in maturity. For occasionally, the mental or inner lexicon has been engaged with a mental or inner dictionary both keeping and operating word awareness; however, they are dissimilar in construction and numbers or grade of information [3]

Like the World Wide Web, the inner lexicon is established through some legal actions that develop forwardly in cognition or awareness, embarking from the insert process, repository, and taking [4]. The technique of investigation for this research is a modest word affiliation test. Word affiliation test (WAT) is a certain form of psycholinguistic inquiry applies both in initial and secondary language acquisition research to explore the lexical contact personals withstand in their expansion of mental lexicon [5]. The name affiliation is utilized in psycholinguistics to indicate an affiliation between ideas, words, or thoughts which abide in the human mastermind and indicates after the manner: an 
appearance of one existence brings the presence of the other in the mind. [6] The researcher relates word association tests with the song that taught in English class to see how deep their understanding of the word and related word in their mind, so that the song study is easier to reach to the students. From this association test, the students could strengthen their words and mean then apply them to a real conversation in daily life.

Exploring connections between words offers bits of knowledge into both construction language and the impact of cognitive or awareness in linguistics tasks. Thus, awareness network learning quickly appears among organized statistical mechanics, cognitive science, and network theory, [7]. In the free word association test, the significant thing that should be disclosed is the reaction to every improvement stimulus word. At that point, the aftereffect of the word association test tends to be seen as the association and/or semantic gap between a single word and another [8].

Consequently, network designs in several structures and unforeseeable have been suggested beneath the correlated rooftop. The intelligent enactment model expects three degrees of handling (highlight, letter, and word) which happen at the same time with excitatory or inhibitory collaboration [9]

Diverse manifestations are implicating oralwritten, written-written, and oral-oral stimulus-response method in WAT. Several WATs call subjects to respond with the initial word they figure of, on the other hand, others involve correspondence to offer several words as they can within a provided time [10]. Examining the necessity of lexical knowledge, it is notable for us, as a language implementer, to present the best pedagogical implementation to encourage the students' lexical progress [11].

One fundamental discovery is that original speakers have a constant design of word affiliation, which may be brought out to portray the sophisticated semantic networks and lexical that they have expanded over their acquisition of the language. On the other hand, secondary language scholar generates associations that are more dissimilar and unsettled; it often they generate the responses, not by semantic however solely on phonological, and affiliate with the stimulus words [12].

There are several significant distinctions between the inner lexicon and the conventional dictionary. First, different from a basic dictionary, the inner lexicon is not arranged in alphabetical sequence. Second, a dictionary embodies a restricted amount of words and frequently cannot maintain rapidity with the lasting expansion of a language; in comparison, the inner lexicon can unceasingly adjust to the emersion or vanish of words as nice as to shift in their pronunciations and meanings. Third, terms in dictionaries are registered in disconnection, whilst terms in the inner lexicon are clustered based on certain possession and intercourse [13].

Be that way possible, WATs is not merely pastime or "scientific attention", they provide meaningful data consider the fundamental of the psychological vocabulary list and how terms are collected [14] Most of the time WAT involve the testtaker to select a synonym for a stimulus word or appraise the word knowledge embedded in a Reading comprehension test to measure vocabulary knowledge through numerous option design [15].In most cases of the word, affiliation literacy concentrates on two main primary fundamentals of language: Paradigmatic relation and Syntacmatic relation. Paradigmatic relation implicates separate terms to substitute the target term. Syntacmatic relation affiliated by syntactic structure or phrase [5].

Table 1. Classification word types based on Peppard 2007 $\begin{array}{cc}\text { Paradigmatic Relations Syntagmatic Relations } & \begin{array}{c}\text { Phonological and } \\ \text { Orthographical } \\ \text { Relations }\end{array} \\ & \end{array}$

\begin{tabular}{|c|c|c|}
\hline $\begin{array}{l}\text { 1) Co-ordination } \\
\text { Co-ordination(contain } \\
\text { antonymy)points out to } \\
\text { term "on the similar stage } \\
\text { of specification "e.g. 'cat' } \\
\text { and'dog'. Co-ordination } \\
\text { and antonymy canbe } \\
\text { forward classifiedinto } \\
\text { accomplishing, mutual } \\
\text { incompatibles, converses, } \\
\text { and gradable antonyms. }\end{array}$ & $\begin{array}{l}\text { 1) Collocation } \\
\text { Collocation(Which } \\
\text { means placing together') } \\
\text { is the inclination for } \\
\text { several tems to normally } \\
\text { co-occur together. These } \\
\text { co-occurrences are not } \\
\text { disordered andcan be } \\
\text { either grammatical or } \\
\text { lexical }\end{array}$ & $\begin{array}{l}\text { It is often called 'clang' } \\
\text { too. Poor stage scholars } \\
\text { and children are more } \\
\text { liable to generate } \\
\text { phonetically and classify } \\
\text { them into clang } \\
\text { classification. This is due } \\
\text { to their incompetence to } \\
\text { make umplarned } \\
\text { collocational affiliations } \\
\text { and occasionally }\end{array}$ \\
\hline $\begin{array}{l}\text { 2) Hyponymy and } \\
\text { Hypemymy } \\
\text { Hyponymy emphasizes the } \\
\text { class system comection of } \\
\text { subordination (hyponymy) } \\
\text { and superordination } \\
\text { (hypemymy). 'Dog' is } \\
\text { hyponymy from'Pet' in } \\
\text { tum, a 'Pet' is hypemymy } \\
\text { from 'Dog'. }\end{array}$ & $\begin{array}{l}\text { 2) Multi-Word Items } \\
\text { A several or multi-word } \\
\text { itemis a tem that points } \\
\text { out to expression or } \\
\text { phrase or a cluster of } \\
\text { terms thatpurposes as } \\
\text { sole lexicalitems. It } \\
\text { close to the idiom for L2 } \\
\text { leamers. }\end{array}$ & $\begin{array}{l}\text { mishearing the stimulus } \\
\text { word from the subject. } \\
\text { such as 'nnow' and } \\
\text { knight', or caused by } \\
\text { related promunciation } \\
\text { rather than meaning, e.g. } \\
\text { first } \rightarrow \text { fast; finally } \rightarrow \\
\text { formally, or it can be like } \\
\text { the silent ' } \mathrm{k}^{\prime} \text { 'in 'knife' and } \\
\text { know' }\end{array}$ \\
\hline $\begin{array}{l}\text { 3) Synonymy } \\
\text { If two tems can be utilized } \\
\text { exchangeable in entire } \\
\text { sentence conditions, they } \\
\text { are stiff synonyms. } \\
\text { example; 'High' and 'Tall' }\end{array}$ & $\begin{array}{l}\text { 3) Encyclopedic } \\
\text { Knowledge } \\
\text { These responses are } \\
\text { related to one's } \\
\text { knowledge acquired over } \\
\text { time and create a web- } \\
\text { like set of associations in } \\
\text { target words to make a } \\
\text { response. }\end{array}$ & \\
\hline
\end{tabular}


The research is descriptive since the researcher used the test to gather the data and after that describe them in word and less number in this research. The table and diagram is an image to support the research. The word affiliation test administrated visually nearly or half of the target and vocally to the almost or another half, however since these days it seems difficult due to the outbreak of Corona Virus-19 then the researcher determines the test based online. The researcher makes a test in Google form and spread it to the student's senior high school 1 Sungai Aur group. While distributing the test, the correspondents were provided to write down the initial terms or words that come into their minds after seeing the stimulus word. After that the researcher analyzes them divide them into association types based on Peppard 2007 and then find how students' understanding the word and help them in the song study. Some keywords are supplied to correspondence as stimulus words. Each learner receives the test providing some of the stimulus words in the following sequence:

Table 2. Stimulus words and the reason why they are chosen

\begin{tabular}{|l|l}
\hline Stimulus & Reason for choosing stimulus \\
\hline Book & Word class that close to the students' life \\
\hline Red & The adjective type of word and bright color \\
\hline Rain & A noun word and very memorable time to most people \\
\hline Dark & $\begin{array}{l}\text { The opposite of bright and common in daily scrub of } \\
\text { the students }\end{array}$ \\
\hline Car & A noun word and every day see in the street \\
\hline Computer & A word class that familiar with students \\
\hline Paper & A noun and often seem in the class \\
\hline Cow & Noun word and often to see by students \\
\hline
\end{tabular}

\section{DISCUSSION}

Overall 256 responses are collected for the thirty-two respondents. First, the responses were classified into syntagmatic, phonological associations and paradigmatic; then responses were forward classified into synonymy, hyponymy/ hypernymy, and co-ordination. Then the researcher also divides them into syntagmatic that were further classified into encyclopedic knowledge and multi-word item. The frequency of encyclopedic responses was higher here. Then there is clang (phonological and Orthographical Relations) that will be seen rare in the outcome of the research. Categories the responses was burned the time and complicated ever since many responses should be categorized as either syntagmatic or paradigmatic believing on the idea legal action of the correspondent. For example, some students answer to the stimulus word 'car' with 'motorcycle then, the researcher divides them into hyponymy of it however it also can be synonymy from the car. So it takes time to analyze them.
Classifying result also has some similarity with this result, it takes time and sometimes confuses where this response should put on, such as some students answer to the stimulus word 'Red' with 'light'. This may be paradigmatic: because 'red and light' have a connected relationship between them in daily activity. Or it can be syntagmatic/ collocational as in 'red-light'. [10]

The draft of frequency word concern oftentimes utilized words are recognized forward quick than infrequently terms and a positive connection established between the several terms is showed and straightforward with which they are admitted. As a language mentor, the outcomes are very educative and informative as to how learner creates an inner connection with their L2 lexicon. As the table represents, when the correspondents at every competence stage generate the syntagmatic and paradigmatic answer to stimulus word, they generated a few clang responses. However, both numbers of syntagmatic ones and clang ones could cover up the numbers of paradigmatic responses over the three competence levels. It means that paradigmatic is a higher number between all responses. It is because, in paradigmatic, students find them easy and relate to their environment. Almost $70 \%$ of the paradigmatic result is based on antonym, synonym, and hyponymy.

Table 3. The Response of Students and frequency of them

\begin{tabular}{|c|c|c|c|c|c|c|c|}
\hline Red & Book & Dark & Rain & Car & Paper & Computer & Cow \\
\hline $\begin{array}{l}\text { White: } 8 \\
\text { Blood: } 6 \\
\text { Color: } 5 \\
\text { Blue:3 } \\
\text { Green: 2 } \\
\text { Beautiful: } \\
1 \\
\text { Black: } 1 \\
\text { Leaming: } \\
1 \\
\text { Light: } 1 \\
\text { Shoe: 1 } \\
\text { Apple: } 1 \\
\text { Red: 1 } \\
\text { Merah: 1 }\end{array}$ & \begin{tabular}{|l} 
Pen: 13 \\
Read:4 \\
Paper: 3 \\
Library: 2 \\
Harry \\
Potter: 1 \\
Page: 1 \\
Reading: \\
1 \\
School: 1 \\
Square: 1 \\
Students:1 \\
Teacher:1 \\
White: 1 \\
Book: 1 \\
Buku: 1
\end{tabular} & \begin{tabular}{|l} 
Black:9 \\
Light: 7 \\
Night:6 \\
Bad: 1 \\
Bright: 1 \\
Color: 1 \\
Lamp: 1 \\
Light \\
dark: 1 \\
Ligth \\
(misspel \\
ling):1 \\
White: 1 \\
Deep:1 \\
Dark: 1 \\
Gelap: 1
\end{tabular} & $\begin{array}{l}\text { Water: } 7 \\
\text { Summer:2 } \\
\text { Wet: } 4 \\
\text { Could:2 } \\
\text { Cold: } 2 \\
\text { Cool:2 } \\
\text { Bright: } 1 \\
\text { Dry: } 1 \\
\text { Heat: } 1 \\
\text { Hot: } 1 \\
\text { Memory:1 } \\
\text { Sad: } 1 \\
\text { Shower: } 1 \\
\text { Umbrella: } \\
2 \\
\text { Weather:1 } \\
\text { Winter: 1 } \\
\text { Hujan: } 1\end{array}$ & 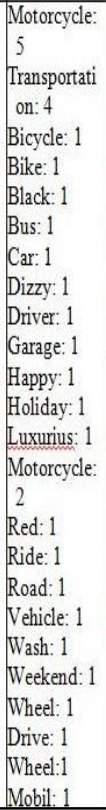 & $\begin{array}{l}\text { White: } 8 \\
\text { Book: } 5 \\
\text { Pencil: } 2 \\
\text { Writing: } 2 \\
\text { Thesis: } 3 \\
\text { Eraizer: } 1 \\
\text { Note: } 1 \\
\text { Pen: } 1 \\
\text { Pena: } 1 \\
\text { Study: } 1 \\
\text { Teacher: } 1 \\
\text { Thyn } \\
\text { (misspellin } \\
\text { g): 1 } \\
\text { Woods: } 1 \\
\text { Write: } 2 \\
\text { Writing: } 1 \\
\text { Xerox: } 1 \\
\text { Pencil: } 1 \\
\text { Paper: } 1 \\
\text { Kertas: } 1\end{array}$ & 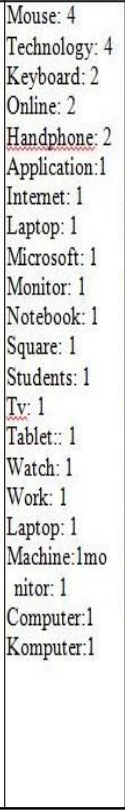 & $\begin{array}{l}\text { Milk: } 9 \\
\text { Animal: } 3 \\
\text { Grass: } 3 \\
\text { Sheep: } 2 \\
\text { Animals: } 1 \\
\text { Ant: } 1 \\
\text { Big: } 1 \\
\text { Black white: } \\
1 \\
\text { Buffalo: } 1 \\
\text { Camel: } 1 \\
\text { Cattle: } 1 \\
\text { Goat: } 1 \\
\text { Grass:1 } \\
\text { Meat: } 1 \\
\text { Sheep:1 } \\
\text { Shepherd; } 1 \\
\text { goat: } 1 \\
\text { Milk: } 1 \\
\text { Sapi: } 1 \\
\text { Cow: } 1\end{array}$ \\
\hline
\end{tabular}

As the result above the researcher divides them into their classes and finds that encyclopedic knowledge 
from students also gives an effect for this researcher. For instance, such as the response from 'book' s harry potter and 'students' explains that the students like to read harry potter when she has time, and she is excited to see all pages from the book. From the student's response, when the researcher asked the students why he makes this response the answer is because students indicate with the book. students are bringing books every day to school, make an assignment in the book, and also the teacher asked them to read the book every day, so it makes him conclude that where is the book, there are students.

Then also we can see from the car response that there is an answer 'dizzy'. This is based on the experience of the students when every time she rides the car; she got dizzy and wants to throw up in the car. This is encyclopedic knowledge. Many of these responses are encyclopedic knowledge and researcher think is a good thing because it also can relate with song study when they learn in class. It can expand the student's vocabulary and make them enjoy English learning.

\section{CONCLUSION}

The researcher wants to relate the mental lexicon of students and bring them in word association test to see how deep understanding of students in vocabulary. The song study is a fun learning for students and researchers want to see the vocabulary in their mind, so it easier for the teacher to find the material, prepare the media, and adjust the level of students. Then the result from this word association test at Senior high school students is almost average in paradigmatic and syntagmatic.

In paradigmatic, co-ordination is the biggest result from four of them (co-ordination, hypernymy, and meronymy, then synonymy). In syntactic, encyclopedic knowledge has the biggest result rather than word item and collocation. However, in phonology and orthographical relation, it has few responses of them. The researcher claims it because they already in senior high school and have knowledge in English vocabulary and associate them to give the response.

\section{REFERENCES}

[1] J. Aitchison, Words sise Pin Oxford: John Wiley \& Sons, Inc., 2012

[2] M. Tamariz, M. Mirêlis, Exploring the Adaptive Structure of the Mental Lexicon, Edinburgh. 2004

[3] L. De Sousa. Bender, R. Gabriel, "Does the mental lexicon exist?" Revista de Estudos da Linguagem, Belo Horizonte, v. 23, n.2, p. 335-361, 2015

[4] B. Pranoto, L. K. Afrilita. The Organization of Words in Mental Lexicon: Evidence from Word Association Test, Teknosastik, Volume 16 (1), 2018
[5] J. Peppard, Exploring the relationship between wordassociation and learners' mental development. Wired, July 2007, from http://www.birmingham.ac.uk/ documents/ college.../peppardmod2.pdf. 25 January 2020

[6] İ. IstifÇi, Playing with words: A study on Word Association Responses. The Journal of International Social Research Volume 3 / 10 Winter, 2010

[7] M. Stella. N. M. Beckage, M. Brede \& M. D. Domenico, "Multiplex model of mental lexicon reveals explosive learning in humans." SCIEnTIFIC ReportS, 8:2259, DOI:10.1038/s41598-018-20730-5, (2018)

[8] A. Prihatini, "Semantic Network of the Word Association in the Field of Law." LITERA, Volume 18, Nomor 3, November 2019

[9] O. Y. "Kwong, Exploring the Chinese Mental Lexicon with Word Association Norms." in 27th Pacific Asia Conference on Language, Information, and Computation pages $153-162,2013$

[10] P.C. Wharton, "The effectiveness of retrospective interview in L2 word association research." Wired in 2010, from http:// jalt publications.org/archive/proceedingsE048. 13 February 2020

[11] F. Ghaemi, S. P. Halimi, "The Study of Iranian EFL Learners' Mental Lexicon through Word Association Tests" Journal of Educational, Health, and Community Psychology, Vol. 4, No. 2, ISSN: 2088 3129,2015

[12] B. Khanzaeenezhad, A. Alibabaee, "Investigating the role of L2 language proficiency in word association behavior of L2 learners: A case of Iranian EFL learners". Theory and Practice in Language Studies, Vol. 3, No. 1, pp. 108-115, January 2013. ACADEMY PUBLISHER Manufactured in Finland. doi:10.4304/tpls.3.1.108-115. ISSN 1799-2591

[13] H. Q. He, Y. F. Deng, "The Mental Lexicon and English Vocabulary Teaching, English Language Teaching", Vol. 8, No. 7; ISSN 1916-4742 E-ISSN 1916, 2015.

[14] Meara, P. Connected words: "Word associations and second language vocabulary acquisition". Amsterdam: John 2009.

[15] S. J. Agdam, K. Sadeghi. "Two Formats of Word Association Tasks: A Study of Depth of Word Knowledge" English Language Teaching; Vol. 7, No. 10; 2014 ISSN 1916-4742 E-ISSN 1916-4750. 2014. 